PRACE NAUKOWE UNIWERSYTETU EKONOMICZNEGO WE WROCLAWIU

Wyzwania dla spójności Europy -

gospodarka, zrównoważony rozwój, konkurencyjność

ISSN 1899-3192

e-ISSN 2392-0041

\title{
Sylwana Kaźmierska
}

Uniwersytet Łódzki

e-mail: sylwana.kazmierska@uni.lodz.pl

\section{POLITYKA UKIERUNKOWANA TERYTORIALNIE JAKO NOWE PODEJŚCIE DO PROCESÓW KLASTERINGU}

\section{PLACE BASED POLICY AS A NEW APPROACH TO CLUSTER PROCESSES}

DOI: $10.15611 /$ pn.2017.466.13

Streszczenie: Inicjowanie budowy klastrów jest od szeregu lat w krajach Unii Europejskiej wiodącą ideą aktywizacji regionalnej. Za najbardziej preferowany dotąd model tej polityki w krajach Unii Europejskiej można uznać koncepcję tzw. polityki rozwoju w oparciu o klastry (cluster-based policy). W myśl tej koncepcji klastry stają się narzędziem wsparcia i aktywizacji rozwoju regionalnego. Istnieje jednak szereg barier związanych z tą polityką, stawiających pod znakiem zapytania jej dalsze stosowanie. W tym kontekście przeanalizowana zostanie nowa koncepcja polityki regionalnej - tzw. polityka ukierunkowana terytorialnie (place-based policy). Celem artykułu jest porównanie obu tych koncepcji, biorąc pod uwagę ich mechanizmy, a także przedstawienie charakteru barier występujących w realizowanej dotąd polityce klastrowej i argumenty przemawiające za jej przemodelowaniem.

Slowa kluczowe: klastry, polityka regionalna, obszar, polityka ukierunkowana terytorialnie, polityka rozwoju w oparciu o klastry.

Summary: Initiation of cluster structures has been the leading idea of regional activation in the European Union for the past years, as it leads to the process, product and organizational innovation. The concept of the so-called place-based policy can be considered as the most preferred model of this policy in the European Union. According to this concept, clusters are becoming a tool of support and activation of regional development and release their natural entrepreneurship. There is, however, a number of barriers related to this policy that question its further application. In this context, attention should be directed to the new concept of regional policy that is the place-based policy. The aim of the paper is to compare both of these concepts. The author takes into account their mechanisms, presents the nature of barriers existing in the policy pursued so far and provides arguments for its remodeling.

Keywords: clusters, regional policy, territory, place based policy, cluster based policy. 


\section{Wstęp}

Inicjowanie budowy klastrów jako formy współdziałania przedsiębiorstw stało się od szeregu lat w krajach Unii Europejskiej wiodącą ideą aktywizacji regionalnej, która z założenia ma stanowić swoiste panaceum na wzrost innowacyjności i konkurencyjności regionów. Również w Polsce polityka klastrowa stała się elementem polityki innowacyjnej. Wychodzi się bowiem z założenia, że efektywna i konsekwentnie wdrażana polityka klastrowa może prowadzić do przekształcenia się klastrów w regionalne systemy innowacji, charakteryzujące się efektywną absorpcją i tworzeniem innowacji procesowych, produktowych i organizacyjnych.

W kontekście celów tej polityki, klastry należy traktować nie tyle jako sposób rozwoju pojedynczych przedsiębiorstw, a raczej jako mechanizm aktywizacji całych regionów. Pozwalają one tworzyć sieci współpracy i powiązania gospodarcze, których siła oddziaływania wykracza daleko poza lokalne ramy. Innymi słowy, klastry mogą być fundamentem rozwoju regionalnego. $Z$ tego też względu rozwój klasteringu stał się obiektem szczególnego zainteresowania władz publicznych różnego szczebla.

Ważną kwestią stał się więc wybór odpowiedniego modelu polityki rozwoju regionalnego, która może być realizowana $\mathrm{w}$ danym kraju, co wiąże się ściśle $\mathrm{z}$ formą pomocy publicznej, stosowanej dla wspierania rozwoju klastrów. Za najbardziej znany i preferowany dotąd model tej polityki w krajach Unii Europejskiej można uznać koncepcję tzw. polityki rozwoju w oparciu o klastry (cluster-based policy, CBP), której ogólne założenia (mówiąc w uproszczeniu) polegają na odejściu przez organy władzy regionalnej od tradycyjnego bezpośredniego, czy też - mówiąc wprost - ręcznego sterowania lokalną gospodarką na rzecz działań pośrednich i stymulujących rozwój klasteringu. Ostatnie badania dowodzą jednak, że model CBP przynosi często mało satysfakcjonujące efekty, a w jego realizacji dostrzega się szereg barier.

W tym kontekście autorka pragnie zwrócić uwagę na nową koncepcję polityki regionalnej, wiążącą rozwój lokalnych gospodarek z procesami terytorializacji - na tzw. politykę ukierunkowaną terytorialnie (place based policy), która nastawiona jest głównie na wykorzystanie potencjału terytoriów, a także na zmniejszenie nierówności między nimi. Co jest istotne, miejscem interwencji w zakresie tej polityki nie są wyznaczone administracyjnie obszary, lecz miejsca o zbiorach cech (np. społecznych czy historycznych) wyraźnie odróżniających je od reszty kraju. Nadmienić należy, że jest to zagadnienie nowe, które nie doczekało się dotąd wielu opracowań naukowych, zwłaszcza w literaturze polskojęzycznej.

Celem artykułu jest porównanie obu wspomnianych wyżej koncepcji, biorąc pod uwagę ich mechanizmy oraz główne osie działania, a także przedstawienie charakteru barier występujących w realizowanej dotąd polityce klastrowej (CBP) i koncepcji jej przemodelowania. 
Podstawową metodą pozyskiwania informacji stanowiła technika desk research, bazująca na źródłach zagranicznych i rodzimych. Analizując je, posiłkowano się głównie raportami różnych instytucji badawczych zajmujących się problematyką klasteringu, informacjami zawartymi w publikacjach naukowych i czasopismach branżowych, a także treściami opublikowanymi w mediach wirtualnych (takich jak wydawnictwa internetowe czy wirtualne fora naukowe).

\section{Ograniczenia i bariery dotychczasowej polityki rozwoju w oparciu o klastry}

Jeszcze do niedawna wśród części ekonomistów zajmujących się problematyką klasteringu panowało przekonanie, że dotychczasowa polityka wspierania rozwoju regionalnego w oparciu o klastry (cluster-based policy) stanowi przełom w rozwoju gospodarki europejskiej. Korzyści powinny być odczuwalne dla całego regionu, a nie tylko zaangażowanych $\mathrm{w}$ dany projekt podmiotów. Nastawiona jest także na wzrost konkurencyjności sektora małych i średnich przedsiębiorstw oraz stymulowanie poszczególnych regionów i zwiększanie ich atrakcyjności ${ }^{1}$. Zdaniem wielu ekonomistów oraz badaczy zaangażowanych w proces estymacji efektywności polityki klastrowej, dotychczasowa praktyka wskazuje jednak, że w nikłym stopniu przyczynia się ona do faktycznego rozwoju tych struktur klastrowych, które odnosiły największe sukcesy. $Z$ szeregu opublikowanych raportów badawczych wynika, że wprowadzanie cluster-based policy napotyka w praktyce szereg zróżnicowanych barier rozwojowych. W efekcie jej skutki są mało satysfakcjonujące w odniesieniu do nakładów pracy bądź środków finansowych przeznaczonych na wspieranie określonych inicjatyw klastrowych.

Przyjmując określone kryteria podziału, które pozwolą dokonać bardziej usystematyzowanej analizy, można wyodrębnić następujące 4 zasadnicze typy barier rozwojowych:

- Bariery instytucjonalne sprowadzające się do relacji miedzy już działającymi i potencjalnymi członkami klastrów a organami administracji samorządowej, rządowej i instytucjami otoczenia biznesu.

- Bariery organizacyjno-systemowe odnoszące się do rzeczywistego kształtu polskiej gospodarki, do jej poszczególnych segmentów, w tym w szczególności sektora $\mathrm{B}+\mathrm{R}$ oraz systemu finansowania inicjatyw klastrowych.

- Bariery typu rynkowego to trendy w globalnej gospodarce, wzrost konkurencyjności, ryzyko recesji i kryzysów.

${ }^{1}$ Polityka oparta na klastrach może być realizowana z inicjatywy odgórnej, tzn. być efektem działań podjętych przez władze państwowe czy samorządowe, lub też może się wyłonić dzięki inicjatywom oddolnym, tj. dzięki mobilizacji środowisk biznesowych. W praktyce jednak najczęściej napotykamy współistnienie obu podejść - oddolnego i odgórnego [Ministerstwo Rozwoju 2014]. 
- Wreszcie bariery mentalne, które należy utożsamiać z czynnikami społeczno-kulturowymi, z deficytem zaufania społecznego, z zakorzenionymi zasadami współpracy.

Ograniczenia wynikają tu w głównej mierze z zakorzenionych zasad współpracy między podmiotami klastra oraz deficytu zaufania między nimi. Deficyt ten tworzy często niekorzystną atmosferę do budowy struktur klastrowych, które oparte są właśnie na zaufaniu.

Poniżej przedstawiono w formie tabelarycznej kompleksowe ujęcie każdego typu wymienionych wyżej barier.

Tabela 1. Bariery i ograniczenia rozwojowe klastrów

\begin{tabular}{|c|c|c|c|}
\hline Instytucjonalne & Organizacyjno-systemowe & Rynkowe & Mentalne \\
\hline $\begin{array}{l}\text { Niedostateczny rozwój } \\
\text { instytucji otoczenia } \\
\text { biznesu }\end{array}$ & $\begin{array}{l}\text { Słaba współpraca firm } \\
\text { w zakresie B }+ \text { R }\end{array}$ & $\begin{array}{l}\text { Niski poziom } \\
\text { innowacyjności } \\
\text { gospodarki }\end{array}$ & $\begin{array}{l}\text { Deficyt zaufania } \\
\text { społecznego }\end{array}$ \\
\hline $\begin{array}{l}\text { Niezreformowany sektor } \\
B+R\end{array}$ & $\begin{array}{l}\text { Słabe formalne powiązania } \\
\text { między podmiotami życia } \\
\text { gospodarczego }\end{array}$ & $\begin{array}{l}\text { Ograniczone } \\
\text { środki finansowe }\end{array}$ & $\begin{array}{l}\text { Dominacja } \\
\text { paradygmatu } \\
\text { konkurencji }\end{array}$ \\
\hline $\begin{array}{l}\text { Biurokracja, która } \\
\text { ogranicza dostępność } \\
\text { do środków publicznych }\end{array}$ & $\begin{array}{l}\text { Płytkie formy współpracy } \\
\text { w życiu gospodarczym }\end{array}$ & $\begin{array}{l}\text { Niewielka liczba } \\
\text { uzyskiwanych } \\
\text { patentów }\end{array}$ & $\begin{array}{l}\text { Słabe fundamenty } \\
\text { społeczeństwa } \\
\text { obywatelskiego }\end{array}$ \\
\hline \multirow{2}{*}{$\begin{array}{l}\text { Niedomagania } \\
\text { administracji } \\
\text { samorządowej i adm. } \\
\text { centralnej }\end{array}$} & $\begin{array}{l}\text { Słabe współdziałanie } \\
\text { przedsiębiorców } \\
\text { z sektorem B + R }\end{array}$ & $\begin{array}{l}\text { Brak innowacji } \\
\text { na skalę } \\
\text { międzynarodową }\end{array}$ & $\begin{array}{l}\text { Słabość inicjatyw } \\
\text { publicznych } \\
\text { (oddolnych) }\end{array}$ \\
\hline & $\begin{array}{l}\text { Braki w sferze } \\
\text { legislacyjnej }\end{array}$ & $\begin{array}{l}\text { Uzależnienie } \\
\text { od środków } \\
\text { publicznych }\end{array}$ & $\begin{array}{l}\text { Niezrozumienie } \\
\text { idei klasteringu }\end{array}$ \\
\hline
\end{tabular}

Źródło: opracowanie własne na podstawie [Lindqvist i in. 2013; Plawgo 2014].

Przedstawione w tabeli 1. bariery rozwoju klastrów w Polsce nie wyczerpują ich pełnej listy; przeciwnie, ma ona charakter otwarty. Należy sądzić, że w miarę popularyzowania idei klasteringu mogą być do niej dopisywane kolejne utrudnienia i przeszkody.

Za wartą podkreślenia barierę rozwoju klastrów uważa się również brak spójnej logiki i konsekwencji w działaniach współpracujących podmiotów. W analizowanych opracowaniach i raportach wskazuje się, że podejmowane przedsięwzięcia są realizowane bez spojrzenia długofalowego, zakładającego, że powzięte kroki będą miały na rozwój danej struktury wpływ w dłuższym horyzoncie czasowym [Szymoniuk 2014, s. 213]. Powyższe spostrzeżenie dotyczy zarówno koordynatorów i uczestników klastrów, jak i sfery samorządów [Miller 2006]. Do istotnych utrudnień zaliczane są także wadliwie zaprojektowane procedury, które narzucane są 
na struktury klastrowe. Przejawiają się one w nadmiernej biurokratyzacji procesów oraz ich nieprzejrzystości [Plawgo 2014, s. 134].

Zaprezentowane powyżej bariery rozwoju klastrów nie wyczerpują listy utrudnień, z jakimi borykają się członkowie i koordynatorzy klastrów. Niewątpliwie szereg z nich wywiera negatywny wpływ na kształt i rozwój klasteringu w Polsce.

\section{Istota modelu polityki rozwoju ukierunkowanej terytorialnie}

Alternatywę dla scharakteryzowanego wyżej podejścia stanowi koncepcja polityki opartej na terytorium ${ }^{2}$, nazywanej także polityką ukierunkowaną terytorialnie (place-based policy). Jej najważniejsze założenia, cytowane przez wielu badaczy, opisane zostały w raporcie stworzonym przez Frederico Barcę, ekonomistę i byłego ministra ds. spójności terytorialnej Włoch [Barca 2009]. Raport ten, uznawany przez wielu badaczy za przełomowy [Strzelec 2010, s. 174], stworzony został m.in. na postawie badań przeprowadzonych przez przedstawicieli takich instytucji, jak Centrum Badań nad Polityką Europejską, Europejski Bank Inwestycyjny, czy London School of Economics [Barca 2009]. Jej zwolennicy są zdania, że większe możliwości rozwoju istnieją w nieeksploatowanych dotąd peryferiach ośrodków gospodarczych, a nie w ich punktach centralnych. Ich potencjał może zostać jednak wykorzystany poprzez taką politykę, która jest indywidualnie dopasowana do uwarunkowań danego terytorium [Varga 2015]. Pojęcie „terytorium” jest w tym przypadku pojęciem kluczowym.

Polityka ukierunkowana terytorialnie jest kierunkiem, w jakim obecnie podążają twórcy modelu polityki spójności Unii Europejskiej. W swych założeniach odchodzi ona od dotychczasowego modelu redystrybucji środków, w którym podstawą do uzyskania wsparcia był m.in. słaby poziom rozwoju danego obszaru, na rzecz wspierania rozwoju terytoriów charakteryzujących się dużym, niewykorzystanym potencjałem. Uznając powyższe założenie za słuszne, place-based policy opiera się na koncepcji wspierania określonych terytoriów oraz na wspomaganiu danych obszarów w zależności od ich cech szczególnych i charakterystycznych dla nich potrzeb. Brane są więc pod uwagę powiązania pomiędzy podmiotami działającymi na danym terytorium, ich przyzwyczajenia i relacje zachodzące między nimi. W zależności od nich dobiera się, w ramach programu pomocy, odpowiednie narzędzia wspierania. Narzędziami tymi nie są jednak, jak było to w starym paradygmacie polityki regionalnej, wyłącznie subsydia i dotacje publiczne.

\footnotetext{
${ }^{2}$ Terytorium traktowane jest tu przestrzeń życia, współpracy i wymiany między podmiotami, których tożsamość kształtowana jest w ścisłym związku z zamieszkanym terytorium. Pojęcie to jest często utożsamiane z pojęciem „regionu”, natomiast obecnie uważa się, że o ile granice regionu są zazwyczaj z góry określone (na przykład w wyniku wyznaczania granic administracyjnych), o tyle granice terytorium są budowane przez historię i kulturę. Szerzej o tym piszą: G. Garofoli, Le Berre, A. Jewtuchowicz, A. Nowakowska.
} 
Raport OECD, traktujący o wskazaniach polityki ukierunkowanej terytorialnie [OECD 2009], wyraźnie wskazuje dwa odrębne cele, do których działania place-based policy mają prowadzić: cel zmniejszenia nierówności społecznych i gospodarczych pomiędzy terytoriami oraz zwiększenie ich efektywności. Cele niniejszego artykułu skłaniają do skupienia się na drugim z wymienionych celów, a mianowicie na kwestii pełnego wykorzystaniu potencjałów poszczególnych terytoriów. Kierunki działań tej polityki względem owego priorytetu zostały dokładniej ukazane w tabeli 2.

Tabela 2. Założenia oraz metody polityki ukierunkowanej terytorialnie w kontekście celu pełnego wykorzystania zasobów

\begin{tabular}{|l|l|}
\hline \multicolumn{1}{|c|}{ Założenia celu } & \multicolumn{1}{c|}{ Metody osiągania celu } \\
\hline - Podnoszenie efektywności & - Dopasowanie rodzaju interwencji do kontekstu określonych \\
gospodarek lokalnych & działań \\
- Wydobywanie ukrytych & - Kreowanie kanałów współpracy z otoczeniem biznesowym \\
potencjałów & - Wydobywanie korzyści z rozwijania sieci kontaktów \\
w ramach terytoriów & pomiędzy aglomeracjami \\
- Odejście od faworyzowania & - Pozyskiwanie rzetelnych informacji opartych na \\
kategorii aglomeracji & szczegółowych badaniach \\
\hline
\end{tabular}

Źródło: opracowanie własne na podstawie [Barca 2009].

Cel efektywności działań stanowi jedną z głównych osi działań polityki ukierunkowanej terytorialnie. Opiera się on na założeniu, że potencjał danego obszaru jest kategorią endogeniczną, kreowaną oddolnie. W rezultacie terytoria są w stanie wytworzyć i kumulować swoje własne, nienarzucone z góry przewagi. Rolą władz publicznych jest zatem dopasowanie rodzaju interwencji do kontekstu określonych działań, a mówiąc inaczej - do naturalnej specyfiki danego terytorium.

Charakterystyczną dla podejścia terytorialnego cechą jest również zmiana podejścia do zasięgu danego terytorium jako do determinanty jego rozwoju gospodarczego. W związku z powyższym takie jednostki osadnicze, jak aglomeracje monocentryczne, konurbacje bądź skupiska jednostek mieszanego typu, tak samo jak miasta niewielkie oraz o charakterze wiejskim, posiadają potencjał do wnoszenia istotnego wkładu w rozwój ekonomiczny regionu. Aby ich produktywność była wysoka, wskazane jest jednak, aby skupiały swoją działalność na tych aktywnościach, do których są najlepiej przystosowane [OECD 2011]. W ten sposób dopuszcza się możliwość, iż skupiska o mniejszej wielkości oraz zagęszczeniu przyczynią się w większej mierze niż wiodące pod względem wielkości miasta do wzrostu gospodarczego kraju. Stawia to więc pod znakiem zapytania zasadność umiejscawiania przez władze na szczycie hierarchii największych miast jako motorów gospodarki regionu bądź kraju.

Obecnie w świecie naukowym panuje przekonanie, iż koncepcja polityki opartej o terytorium stanowi krok naprzód w stosunku do tradycyjnych polityk rozwojowych [Barca 2009]. Celowe byłoby więc podjęcie próby aplikacji jej założeń w ak- 
tualnie realizowanych programach rozwoju bazujących na kategorii regionu, takich jak polityka klastrowa. Niewykluczone bowiem, że postulaty place-based policy dotyczące wydobywania ukrytych potencjałów z terytoriów mogłyby skutecznie skorygować dotychczasowe podejście do klasteringu w Polsce.

\section{Przydatność modelu polityki ukierunkowanej terytorialnie w podejściu do procesów klasteringu}

Obecnie realizowana polityka rozwoju klastrów, także w warunkach polskiej gospodarki, cechuje się, jak wskazano wcześniej, wieloma mankamentami i barierami. Celowe jest więc eksploracja alternatyw dla jej rozwiązań w zdobywających w ostatnich latach popularność nowych modelach rozwoju regionalnego. Należy do nich m.in. omówiony w poprzednim punkcie model place-based policy, który zawiera szereg założeń mogących z powodzeniem znaleźć przełożenie na grunt polskiej polityki regionalnej. Szczególnie odnosi się to do procesów klasteringu, gdzie absorpcja nowych rozwiązań wiąże się ściśle z regionem (terytorium), na którym klastry powstają.

Poniżej podjęto próbę porównania dotychczasowej polityki klastrowej (cluster-based policy), nazywając ją podejściem klasycznym, z nową koncepcją modelu place-based policy, nazywając je nowym podejściem. Porównanie prezentuje tabela 3.

Tabela 3. Klasyczne i nowe podejście do polityki klastrowej

\begin{tabular}{|c|c|}
\hline \multicolumn{2}{|c|}{ Polityka klastrowa } \\
\hline Klasyczne podejście & Nowe podejście \\
\hline $\begin{array}{l}\text { Głównym celem wspieranie rozwoju struktur } \\
\text { klastrowych }\end{array}$ & $\begin{array}{l}\text { Głównym celem rozwój gospodarki } \\
\text { terytorialnej }\end{array}$ \\
\hline $\begin{array}{l}\text { Wspieranie klastrów, które mają wzmacniać } \\
\text { specjalizacje określone na poziomie centralnym }\end{array}$ & $\begin{array}{l}\text { - Dopasowanie polityki regionalnej do } \\
\text { indywidualnych przypadków } \\
\text { - Wykorzystywanie endogenicznych } \\
\text { potencjałów rozwojowych }\end{array}$ \\
\hline $\begin{array}{l}\text { Silny nacisk na interregionalizację klastrów i ich } \\
\text { globalizację }\end{array}$ & $\begin{array}{l}\text { Upatrywanie przewag struktur w ich } \\
\text { bliskości terytorialnej }\end{array}$ \\
\hline Działania poparte oceną ekspercką & Działania poparte badaniami i faktami \\
\hline $\begin{array}{l}\text { - Aplikacja generycznych narzędzi badawczych } \\
\text { - Adaptacja modelowych rozwiązań klastrów } \\
\text { rozwiniętych }\end{array}$ & $\begin{array}{l}\text { Łączenie wiedzy eksperckiej } \\
\text { z doświadczeniem lokalnych praktyków }\end{array}$ \\
\hline
\end{tabular}

Źródło: opracowanie własne.

Tabela 3. ukazuje cechy charakteryzujące dotychczasową politykę klastrową w Polsce i na świecie oraz sugestie jej rekonstrukcji w oparciu o koncepcję nowego modelu. Spośród wszystkich cech charakteryzujących cluster-based policy szczególną uwagę poświęcono tym jej elementom, które wiążą się z barierami rozwoju struktur klastrowych zaprezentowanymi w punkcie pierwszym opracowania. 
Terytorialne podejście do zagadnienia funkcjonowania klastrów w gospodarce stanowi pewnego rodzaju punkt zwrotny w sposobie interpretacji roli struktur sieciowych w rozwoju lokalnym. W tym podejściu sukces danej struktury klastrowej jest nie środkiem, lecz efektem skutecznie realizowanej polityki rozwoju terytorialnego. Place-based policy oznacza więc gotowość na konstrukcję adekwatnych narzędzi, w razie gdy spośród dobrze prosperujących firm wyłoni się potencjał do wytworzenia się struktury sieciowej.

Zgodnie z założeniami place-based policy geograficzna bliskość przedsiębiorców, ich uwarunkowania społeczne i charakter wykształcają się przy partycypacji lokalnej społeczności. To w położonych blisko siebie obszarach o wspólnych cechach charakterystycznych leży - według jej zwolenników - największa przewaga takiej struktury. Sądzi się, iż to wymiar terytorialny jest właśnie siłą napędową klastra niezbędną zwłaszcza w początkowych etapach jego rozwoju3

\section{Zakończenie}

Klastry traktowane są od szeregu lat jako struktury, które poprzez efekty synergii zapewniają gospodarce regionalnej szybszy rozwój. Co za tym idzie, zainteresowanie tą formą struktur sieciowych obserwujemy w całej Unii Europejskiej. W Polsce dotychczasowa polityka rozwoju regionalnego oparta na klastrach nie przynosi jednak oczekiwanych efektów, co w dużym stopniu wynika z bezkrytycznego naśladownictwa zagranicznych wzorców. Jest ona niedopasowana do realiów polskiej gospodarki, do naszych warunków społeczno-gospodarczych, a przez to nieefektywna.

Analiza szeregu raportów badawczych wyraźnie wskazuje, że w Europie brak jest jak dotąd jednego uniwersalnego modelu polityki zarządzania rozwojem struktur klastrowych, co jest zjawiskiem zrozumiałym, biorąc pod uwagę zróżnicowanie i specyfikę gospodarek narodowych. Należy sądzić, że dążenie do unifikowania modelu rozwojowego i traktowania go jako wspólny dla wszystkich krajów UE byłoby błędem.

Przedstawione tezy i przemyślenia stanowią próbę wskazania kierunku dalszego rozwoju polityki klasteringu, uwzględniającego zalety modelu place-based policy. $\mathrm{W}$ aspekcie aplikacyjnym potencjalnie mogą one zostać wykorzystane przez instytucje samorządów terytorialnych i władz publicznych w procesach wspierania inicjatyw klastrowych.

\section{Literatura}

Barca F., 2009, An agenda for a reformed cohesion policy. A place-based approach to meeting European Union challenges and expectations, Niezależny raport sporządzony na prośbę Komisarza ds. Polityki Regionalnej Unii Europejskiej, s. 17.

${ }^{3}$ Oddolny „przymus bliskiego sąsiedztwa” członków grona jest także wykazywany w takich publikacjach, jak Zielona Księga Inicjatyw Klastrowych (zob. [Lindqvist i in. 2013, s. 16]). 
Ebbekink M., Lagendijk A., 2013, What's Next in Researching Cluster Policy: Place-Based Governance for Effective Cluster Policy, European Planning Studies, Radboud University Nijmegen, Nijmegen, s. 745 .

Lindqvist G., Ketels C., Sölvell Ö., 2013, The Cluster Initiative Greenbook 2.0, Ivory Tower Publishers, Stockholm, s. 16.

Miller C.R., 2006, The Tholian Web: The political/institutional context of regional cluster-based economic development", Virginia Polytechnic Institute and State University, Blacksburg 2006.

Ministerstwo Rozwoju, 2014, Serwis programu Inteligentny Rozwój, Zasady działania Programu, https://www.poir.gov.pl/strony/o-programie/zasady/_(10.02.2016).

OECD, 2009, Investing for Growth: Building Innovative Regions, Background Report, Meeting of TDPG on Ministerial Level, Komitet Polityki Rozwoju Regionalnego, Paryż.

OECD, 2011, Regional Outlook 2011, Organisation for Economic Cooperation and Development, Paris.

Plawgo B., 2014, Klastry - stan i perspektywy rozwoju w województwie podlaskim, Białostocka Fundacja Kształcenia Kadr, Białystok, s. 134.

Strzelec J., 2010, Problemy konkurencyjności regionów. Polityka rozwoju ukierunkowana terytorialnie wedtug Fabrizio Barci, Studia i Materiały. Miscellanea Oeconomicae, s. 174.

Szymoniuk B., 2014, Polityka klastrowa - dobrodziejstwo czy przekleństwo dla polskich klastrów?, Prace Naukowe Uniwersytetu Ekonomicznego we Wrocławiu, nr 369, Wrocław, s. 213.

Varga A., 2015, Place-based, Spatially Blind, or Both? Challenges in Estimating the Impacts of Modern Development Policies: The Case of the GMR Policy Impact Modeling Approach, International Regional Science Review, s. 4-5. 